University of Warwick institutional repository: http://go.warwick.ac.uk/wrap This paper is made available online in accordance with publisher policies. Please scroll down to view the document itself. Please refer to the repository record for this item and our policy information available from the repository home page for further information.

To see the final version of this paper please visit the publisher's website. Access to the published version may require a subscription.

Author(s): John Cunliffe, Guido Erreygers

Article Title: The Enigmatic Legacy of Charles Fourier:

Joseph Charlier and Basic Income

Year of publication: 2001

Link to published version: http://dx.doi.org/10.1215/00182702-33-3-459

Publisher statement: None 


\title{
The Enigmatic Legacy of Charles Fourier: Joseph Charlier and Basic Income
}

\author{
John Cunliffe and Guido Erreygers
}

The origins of the idea of a "basic income" remain to be fully explored. An idea with currency mainly in Europe, a basic income is conventionally defined as an income unconditionally granted to all on an individual basis, irrespective of the level of any income from other sources, and without any work requirements. In this article we examine the completely neglected contribution of an elusive Belgian, Joseph Charlier, to the spasmodic history of proposals for a basic income and its cognates. Although crucial aspects of the basic income approach have been traced back to at least the eighteenth century, the conventional belief is that the first fully fledged scheme was formulated in 1919 in England by Dennis Milner under the name "state bonus." 1 We demonstrate that Charlier

Correspondence may be addressed to Guido Erreygers, UFSIA-RUCA, Department of Economics, University of Antwerp, Prinsstraat 13, 2000 Antwerp 1, Belgium; e-mail: guido.erreygers@ufsia.ac.be. The research for this article was made possible by grants from the British Council and the Flemish Fonds voor Wetenschappelijk Onderzoek (FWO) under the British-Flemish Academic Research Collaboration Program, and from the Nuffield Foundation under its Social Science Small Grants Scheme. We thank Andrew Reeve, Luc Peiren (Archief en Museum van de Socialistische Arbeidsbeweging, Ghent), and the staff of the Institut Émile Vandervelde, Brussels, for their assistance when we were working on the first draft of this essay. We are very grateful to Maryline Van Parijs for an extensive genealogical search on Joseph Charlier. Remarks from an anonymous referee and from participants at the 1999 HES conference in Greensboro, North Carolina, enabled us to substantially improve the article.

1. The rediscovery of that scheme must be attributed to the pioneering research of Walter Van Trier (1995, 29-142). Dennis Milner (1892-1956) was an engineer. In his early life he was a Quaker, and he used the Quaker movement to promote the idea of the basic income (or state bonus, as he called it).

History of Political Economy 33:3 @ 2001 by Duke University Press. 
presented a surprisingly modern basic income scheme as early as 1848 and then advocated it in other works over some fifty years.

Despite being reticent about his intellectual ancestry, Charlier acknowledged an initial but not uncritical sympathy with Fourierism. The general affinity between the idea of a basic income and the Fourierist notion of the minimum - that is, a minimum presumably paid in kindhas been indicated in some of the limited discussions of the intellectual origins of the idea, but apparently not subjected to any sustained analysis. ${ }^{2}$ This article analyzes Charlier's scheme and its intellectual pedigree in detail. In the first section, we consider Fourier's view of the minimum and demonstrate that it differed considerably from a modern basic income. The next section reviews the association between the idea of the minimum and the doctrine of the right to work in the thought of Fourier's leading disciple, Victor Considerant. We then examine Charlier's proposals and show that they constitute a genuine basic income scheme that is distinctive and significantly different from its Fourierist precursors.

\section{Charles Fourier}

The suggestion that Charles Fourier was an early proponent of a basic income scheme has been made most clearly by G. D. H. Cole. In his History of Socialist Thought, Cole (1953-60, 1:310) explained John Stuart Mill's sympathy for Fourierism as follows:

Mill did, however, regard as much nearer practicability those forms of socialism which, at a sacrifice of idealism, accepted a moderate degree of economic inequality. On this score he praised the Fourierists, or rather that form of Fourierism which assigned in the first place a basic income to all and then distributed the balance of the product in shares to capital, talent or responsibility, and work actually done.

Mill himself apparently did not use the phrase "basic income" in his writings on Fourierism. Instead he preferred the more vague expression "a certain minimum":

The most skilfully combined, and with the greatest foresight of objections, of all the forms of Socialism, is that commonly known as

2. See Van Parijs 1992, 9-11, and Nozick 1974, 178-79; see also the Web page of the Basic Income European Network (BIEN): www.econ.ucl.ac.be/etes/bien/Origins of_Basic_Income.html. 
Fourierism. This system does not contemplate the abolition of private property, nor even of inheritance; on the contrary, it avowedly takes into consideration, as an element in the distribution of the produce, capital as well as labour.... In the distribution, a certain minimum is first assigned for the subsistence of every member of the community, whether capable or not of labour. The remainder of the produce is shared in certain proportions, to be determined beforehand, among the three elements, Labour, Capital, and Talent. (Mill [1848] 1965, bk. 2, 211-12)

A close textual examination reveals that Mill's characterization is without any doubt the more accurate of the two. In this section we show that Fourier's minimum is certainly not a basic income in the modern sense.

The idea of a social minimum, that is, a minimum of goods determined by the level of subsistence, appears in all of Fourier's major works, both published and unpublished. ${ }^{3}$ We find it in the Théorie des quatre mouvements ([1808]1966-68); in the Traité de l'association domestiqueagricole ([1822] 1966-68), which was reissued later as the Théorie de l'unité universelle (1841-43); in Le nouveau monde industriel et sociétaire ([1829] 1966-68); in La fausse industrie ([1835-36] 1966-68); and even in Le nouveau monde amoureux (1966-68), a collection of texts published only in the 1960s. It also shows up in many of his manuscripts, not all of which have been included in his Euvres complètes.

The earliest mention of a minimum is in his "Lettre au grand juge," written in December 1803. ${ }^{4}$ Fourier characterized poverty (not inequality) as the principal cause of disorder in society, and he proposed to eradicate it by sufficiently high wages and by a "decent minimum" for those who were not able to work. 5 In another manuscript from the same period, "Les trois nœuds du mouvement" (1803-4), he launched the idea that society should give to every poor person a small amount of land. ${ }^{6} \mathrm{~A}$ third

3. For detailed information on Fourier's publications and manuscripts, see Del Bo 1957 and Poulat 1957.

4. On the date of the letter, see Beecher and Bienvenu 1983, $83 \mathrm{n}$. 1. The letter was not published until 1874 (Del Bo 1957, 9) and is not in the Euvres complètes.

5. "When the people enjoy constant comfort and a decent minimum, all the sources of discord will be dried up or reduced to very little" (quoted and translated by Beecher and Bienvenu $[1983,87])$. Parts of this letter can also be found in "Du plan providentiel" ([1806] 1966-68, 289-93).

6. At first he proposed to "accorder un minimum de territoire à chaque individu pauvre" [to give to each poor individual a minimum of land] ([1803-4] 1966-68, 458), but immediately after that he made the stronger proposition that "la société doit garantir à tout individu, par des 
early occurrence is in the introduction to the first edition of La théorie des quatre mouvements ([1808] 1966-68). In a merciless attack on philosophy and the "inexact" sciences in general, Fourier accused "reason" of having contributed nothing at all to a solution of the problem of providing each member of society with a relative degree of comfort. ${ }^{7} \mathrm{Al}-$ though Fourier may not always have used the term social minimum in the same sense, we may safely say that the following three characteristics are fundamental: (1) the minimum is destined for the poor; (2) the minimum is paid in kind; and (3) the minimum is advanced without any work requirement on the part of those who receive it. The main goal of the minimum was certainly not the reduction or elimination of inequality, but rather the eradication of poverty, by guaranteeing to every member of society a minimal standard of living. This standard of living should be at least high enough to cover the basic necessities of life, consisting of (subsistence) food, clothing, and housing. ${ }^{8}$ In some places Fourier gave detailed indications of the composition of the minimum. ${ }^{9} \mathrm{~A}$

mesures quelconques, un minimum de terre labourable (avec les instruments nécessaires), qui peut fournir amplement à sa subsistance, sans l'éloigner beaucoup de son pays natal" [society must guarantee to each individual, by any means, a minimum of arable land (together with the necessary tools), which is productive enough to cover his subsistence needs and not located too far away from his native land] (459). It should be noted that this is the only instance in which Fourier interprets the minimum in terms of a (land) endowment.

7. “La Raison, quelque étalage qu'elle fasse de ses progrès, n'a rien fait pour le bonheur tant qu'elle n'a pas procuré à l'Homme cette fortune sociale qui est l'objet de tous les vœux; et j'entends par FORTUNE SOCIALE, une opulence graduée qui mette à l'abri du besoin les hommes les moins riches, et qui leur assure au moins pour minimum, le sort que nous nommons MÉDIOCRITÉ BOURGEOISE" [No matter what exhibition Reason makes of its progress, it has done nothing for happiness as long as it has not provided Man with that social fortune which everybody yearns for. And by SOCIAL FORTUNE I mean a kind of graduated affluence which shelters the least well off from need and which guarantees them at least as a minimum the condition which we call MIDDLE-CLASS MEDIOCRITY] ([1808] 1966-68, 15-16).

8. A typical expression is "un mimimum social, un nécessaire en subsistance, vêtement et logement" [a social minimum, a sufficiency in subsistence, clothing, and housing] ([1822] 1966-68, 2:156). Other expressions used by Fourier include "minimum ou nécessaire" ([1822] 1966-68, 3:39, 43), "minimum, ou honnête nécessaire" ([1829] 1966-68, 35), "minimum sociale ou honnête nécessaire" ([1822] 1966-68, 5:382-83), "minimum d'entretien" ([1822] 1966-68, 3:48, 49; [1835-36] 1966-68, 9:491; [1852] 1966-68, 22, 321), "un nécessaire de minimum d'entretien" ([1852] 1966-68, 22), "minimum d'entretien décent" ([1835-36] 1966$68,8: 9,12,263,374,9: 462)$, "minimum d'entretien et subsistance" ([1852] 1966-68, 20), "minimum décent" ([1822] 1966-68, vol. 2, avant-propos, p. 20; [1829] 1966-68, 336, 339; [1835-36] 1966-68, 9:T3; [1852] 1966-68, 340), "minimum suffisant" ([1822] 1966-68, 3:15; [1829] 1966-68, 29; [1852] 1966-68, 343), and "minimum intégral" ([1822] 1966-68, 5:387, 392, 402).

9. See, for instance, Fourier [1822] 1966-68, 4:445, and [1835-36] 1966-68, 8:288-89. 
few times he spelled out that the minimum should include "pleasure" as well. ${ }^{10} \mathrm{He}$ was confident that in a harmonious state the minimum paid in kind would allow the poor to enjoy a fairly high standard of living above the prevailing level of subsistence. ${ }^{11}$

In some of his writings Fourier apparently gave slightly different meanings to the term (social) minimum. In accordance with his view that economic inequality was both unavoidable and in any case desirable because of its incentive effects, Fourier wanted the introduction of a minimum to leave the existing class structure intact. This could be accomplished by specifying a minimum for each class of society, expressed in the notion of a "proportional minimum." 12 In other places he spoke of a minimum in monetary terms. This occurred when he discussed how in a phalanstery the surplus, and especially the part of it allotted to labor, should be divided. The procedure envisaged by Fourier is rather complicated, but one of its characteristics is that nobody who has made a productive contribution, no matter how rich he or she is, can refuse the minimum share. 13

The justification of these diverse forms of the minimum is largely based upon natural rights entitlements securing the liberty of people to

10. A clear example is "un minimum en subsistance, vêtement, logement, et, de plus, en plaisirs; car le nécessaire sans l'agréable ne saurait suffire à l'homme" [a minimum in subsistence, clothing, housing, and, in addition, pleasure; because the necessary without the agreeable cannot be sufficient for man] ([1822] 1966-68, 3:163). He also used the expressions "minimum de plaisir" and "minimum en jouissance" ([1822] 1966-68, 5:544). In this connection it is interesting to note that in Le nouveau monde amoureux Fourier proposed the notion of a "sexual minimum"; see Beecher and Bienvenu 1983, 55.

11. Witness expressions such as "minimum copieux" ([1829] 1966-68, 3, 10), "minimum abondant" ([1835-36] 1966-68, 9:490, 492), "minimum de subsistance abondante" ([183536] 1966-68, 9:491), "un ample minimum" ([1822] 1966-68, 5:387; [1852] 1966-68, 97), and "minimum supérieur au sort de nos bons bourgeois" ([1822] 1966-68, 5:4). Fourier firmly believed that in a harmonious state the system of attractive labor and association would lead to a massive increase in production.

12. Society should guarantee "un minimum ou nécessaire en aliments, vêtements et logements proportionnés aux trois classes, la haute, la moyenne et la basse. Il faudrait par conséquent trois sortes de minimum pour les pauvres des trois classes" [a minimum or sufficiency in nourishment, clothing, and housing proportionate to the three classes (high, middle, and low). As a result we need three kinds of minimum for the poor of the three classes] ([1822] 196668, 3:169). In other places Fourier used the terms "minimum proportionnel" ([1822] 1966-68, $2: 202,3: 171,182,4: 270,5: 380,493,553$; [1829] 1966-68, 291; [1835-36] 1966-68, 8:356) and "minimum gradué" ([1822] 1966-68, 3:177, 4:582, 583; [1829] 1966-68, xij).

13. Cf. "le taux de minimum, huit fr., qu'on ne peut pas refuser" [the minimum ratio, eight francs, which one cannot refuse] ([1822] 1966-68, 5:504), "le minimum que chacun accepte par bienséance, pour ne pass'isoler d'association" [the minimum that everybody accepts for 
earn their own subsistence. The entitlements are variously classified, but the four cardinal ones are the rights of hunting, fishing, gathering, and grazing. ${ }^{14}$ These rights could be exercised effectively in a state of nature, but not any longer in civilization. One of the problems with civilization was that it offered no real equivalent or indemnity for their loss. Fourier argued that if people were deprived of their natural rights to earn their subsistence, then society should at least make sure that its most vulnerable members would not starve to death. This meant that a decent social minimum had to be guaranteed to the poor. ${ }^{15}$ Fourier not only criticized civilization for failing to offer an equivalent in the form of a social minimum; he also tried to show that even if it attempted to do so, the result would most certainly be a complete disaster. If a social minimum were to be guaranteed, one of its consequences would be widespread idleness, as individuals would then have an alternative to the intrinsically unrewarding "repugnant" labor they had been forced to endure solely to secure a livelihood. 16

the sake of convenience, in order not to be isolated from the association] (508), and "un riche harmonien se trouve assez payé d'un travail attrayant, quand il est entouré de sectaires dévoués et fidèles appuis de sa passion. Il regrette que la bienséance l'oblige à accepter un minimum de lot en industrie" [a wealthy harmonian finds himself sufficiently rewarded by attractive labor, when he is surrounded by devoted and loyal sectarians who support his passion. He regrets that convenience obliges him to accept a minimum share in industry] (511); see also [1829] 196668, 316-23. Harmonian is a standard term used in English translations of Fourier's writings; it refers to somebody living in harmony.

14. At one point the set consists of the following: "1. Cueillette, 2. Pâture, 3. Pêche, 4. Chasse, 5. Ligue intérieure, 6. Insouciance," and "7. Vol extérieur" [gathering, grazing, fishing, hunting, interior league, unconcern, and exterior theft], the first four being designated as "cardinaux ou industriels" and the others as "distributifs" ([1822] 1966-68, 3:164); an almost identical list is given in [1829] 1966-68, xij. In another work, however, the rights mentioned by Fourier are "1. Récolte naturelle, chasse, pêche, cueillette, pâture, 2. Libre essor des sens, 3. Libre essor des âmes, 4. Participation au progrès. 5. Ligue intérieure. 6. Insoucance. 7. Vol extérieur" [natural harvesting, hunting, fishing, gathering, grazing; free development of the senses; free development of the souls; participation in progress; interior league; unconcern; exterior theft] ([1835-36] 1966-68, 9:490). It remains a mystery what Fourier meant by "interior league," "unconcern," and "exterior theft" in this context.

15. But in civilization just the opposite occurred: "Au lieu du minimum qui supposerait une subvention du corps social pour assurer le nécessaire proportionnel aux individus lésés dans les trois classes, riche, moyenne et pauvre, nous n'avons qu'un égoïsme général qui va croissant et habitue chaque civilisé à rester pleinement indifférent sur les besoins de son semblable" [Instead of the minimum, which would suppose a subsidy from the social body in order to guarantee the proportional sufficiency to the disadvantaged individuals in the three classes (rich, middle, and poor), we have only a general egoism which is increasing and which accustoms every civilized person to remain indifferent to the needs of his fellow] ([1822] 1966-68, 3:166).

16. This is a point that Fourier repeats over and over again: "Si le peuple civilisé jouissait d'un minimum copieux, d'une garantie de nourriture et d'entretien décent, il s'adonnerait 
To avoid that outcome, the regime of repugnant labor had to be replaced by one of "attractive" labor, which was intrinsically rewarding. This was one in a set of interconnected conditions that, according to Fourier, would constitute the basis of social equilibrium in the "societary order" destined to replace civilization. Apart from the organization of work around Fourier's famous "passionate series," which brought together men and women sharing the same passion, the conditions involved attractive labor, the minimum, education, and population control. ${ }^{17}$ Crucial in all this is that Fourier first emphasized the necessity of the social minimum, ${ }^{18}$ then pointed out that it could be introduced only if a number of other conditions were simultaneously satisfied, 19 and

à l'oisiveté parce que l'industrie civilisée est très-répugnante" [If civilized people enjoyed a copious minimum, a guarantee of food, and decent support, they would devote themselves to laziness because civilized industry is very repugnant] ([1829] 1966-68, 10). Similar phrases can be found in [1822] 1966-68, 3:16, 39, 49, 172, 5:383, 553; [1829] 1966-68, 3; [183536] 1966-68, 8:12, 9:492; [1852] 1966-68, 20, 22, 94, 97, 343; and [1857-58] 1966-68, $151-52$.

17. "Comment espérer de rallier riches et pauvres, les amener à une affection réciproque, si le pauvre est exposé à tomber dans l'indigence qui est l'épouvantail du riche? Comment assurer au pauvre un minimum intégral, comprenant subsistance, vêtement et logement décents, si on ne sait pas créer l'attraction industrielle, à défaut de laquelle il abandonnerait le travail dès qu'il serait pourvu d'un ample minimum?

“ $\mathrm{D}$ 'autre part, comment réunir amicalement le riche et le pauvre, si celui-ci n'a pas reçu une éducation propre à lui donner le ton et les manières du riche? Enfin, que serviraient les trois propriétés précédentes si le régime sériaire avait, comme le familial, la propriété de population illimitée, produisant des fourmilières sans balance numérique, sans proportion avec les moyens d'aisance générale?" [How can we hope to rally rich and poor, to bring them to a reciprocal affection, if we allow the poor to fall into the poverty that is the horror of the rich? How can we assure the poor an integral minimum, including decent subsistence, clothing, and housing, if we do not know how to make industrial work attractive, without which the poor would abandon work as soon as they were provided with an ample minimum?

On the other hand, how can we unite rich and poor in a friendly way, if the poor have not received an education that would give them the taste and the manners of the rich? And lastly, what good would the three preceding properties be if the regime of passionate series, just as the family regime, were characterized by an unlimited population, producing densely inhabited dwellings without numerical balance, out of proportion to the means of general welfare?] ([1822] 1966-68, 5:387).

18. Cf. expressions like "hors du MINImUm point de salut pour le monde social" [without the MINIMUM the social world is nothing] ([1822] 1966-68, 3:172), "le droit primordial de société, qui est le minimum" [the fundamental right of society, which is the minimum] ([1822] 1966-68, 4:193), and the characterization of the minimum as a "condition sine quâ non de l'harmonie sociétaire" [the condition sine qua non for "societary" (i.e., cooperative) harmony] ([1852] 1966-68, 23).

19. Most clearly explained in [1822] 1966-68, 3:172-77; see also [1822] 1966-68, 5:38081; and [1857-58] 1966-68, 152-54. 
finally arrived at the conclusion that civilization would simply collapse if it tried to satisfy those conditions.

\section{Victor Considerant}

In his capacity as the foremost popularizer and indeed the creator of "Fourierism," Victor Considerant endorsed this conclusion. ${ }^{20}$ His most influential works in the period from 1834 to 1849 repeatedly emphasized the orthodoxy that the provision of a physical minimum could be realized only under conditions of attractive labor. ${ }^{21}$ Considerant pointedly remarked that if a minimum were to be granted under the present industrial regime, then an incentive would be created for a general escape from repugnant labor into widespread idleness. ${ }^{22}$ Since only the social provision of a guaranteed minimum "to each man, each woman, [and] each child" could secure liberty ([1840] 1845, 90-91), he argued that it was imperative to move to an economic regime characterized both by "un ÉNORME ACCROISSEMENT de la richesse publique" and "le TRAVAIL ATTRAYANT" [an ENORMOUS INCREASE of public wealth and by ATTRACTIVE LABOR] $(1848,50)$.

In some of his works, however, Considerant developed an alternative doctrine of the right to work. ${ }^{23}$ This doctrine called for a reform-minded policy applicable even under existing conditions of repugnant labor in which the state would act as an employer of last resort, guaranteeing not only work but also a minimum wage. In order to do so, there would have to be the (planned) "ORGANISATION DU TRAVAIL, ou, pour mieux dire, de l'ORGANISATION DE L'INDUSTRIE" [ORGANIZATION OF WORK, or, to be more precise, the ORGANIZATION OF INDUSTRY] ([1840] 1848, 32). In his

20. That role is examined in two recent works: Davidson 1988 and Vernus 1993.

21. Considerant's main works in that key period were Destinée sociale (1834-44), Théorie du droit de propriété et du droit au travail ([1840] 1848), Exposition abrégée du système phalanstérien de Fourier ([1840] 1845), and Le socialisme devant le vieux monde (1848). In addition, there were his numerous contributions to, and editorship of, successive Fourierist journals: Le phalanstère (1832-34), La phalange (1836-43), and La démocratie pacifique (1843-51).

22. "Il serait impossible aujourd'hui de faire au peuple l'avance du minimum: il tomberait aussitôt dans la fainéantise, attendu que le travail est répugnant" [Today it would be impossible to provide the people with the minimum: they would revert immediately to laziness, since labor is repugnant] (Considerant [1840] 1845, 49; see also Considerant 1848, 50).

23. The key text is Considerant [1840] 1848; see also Considerant 1834-44, 1:153-55. Davidson 1988, 71-73, contains an analysis of Considerant's own doctrine and its connections to Fourier's use of the phrase "right to work." With respect to Fourier's views, see Beecher 1986, 213-14. 
extended justification of the right to work, Considerant distinguished two kinds of capital: the "primitive or natural capital" of all natural resources and especially land; and the "created capital" produced by human labor by means of those resources. Property rights in natural resources should be a collective usufruct of humanity across generations and regardless of location. Provided that this was the case, property rights in created capital should be private, in direct proportion to an individual's contribution and including personal transmission between generations. However, the existing property regimes in civilized societies were based on the usurpation of natural capital by a minority of private landowners. The consequence was that conventional legal titles to property expressed the cumulative effects of natural rights' violations. The excluded majority had not only been deprived of natural rights entitlements but also denied any compensation. The right to work was intended to provide precisely that compensation ([1840] 1848, 34-36).

Considerant's argument for a compensatory strategy was based on a presumption against any radical change to the current concentration of private landownership, especially in the form of equal division. Any such change would be undesirable because it could be achieved, if at all, only by a violent revolution. It would be self-defeating because any initial pattern of equal division would become unequal through time as the population changed. It would entail, moreover, the return to the savage state together with the abandonment of the (potential) advantages of industrialism for all. Above all, it would be superfluous because the natural rights to primitive capital were not rights to equal individual shares in land but those of each person to hunt, fish, gather fruit, and let his or her animals graze on the commons. The issue was not to resurrect those rights in their "primitive and crude FORM," but to find "the form in which [they] could be reconciled with the conditions of an industrious society" ([1840] 1848, 23-24).

For Considerant himself, at least, the solution to that issue was simple. In primitive society, these rights could be exercised only through individual activity. By analogy, in civilized society, the compensation for their violation had to allow each individual the opportunity to engage in productive activity:

Qu'une Société industrieuse, qui a pris possession de la Terre et qui enlève à l'homme la faculté d'exercer à l'aventure et en liberté, sur la surface du sol, ses quatre Droits naturels; que cette Société 
reconnaisse à l'individu, en compensation de ces Droits dont elle le dépouille, LE DROIT AU TRAVAIL: alors, en principe et sauf application convenable, l'individu n'aura plus à se plaindre. [When an industrious Society has taken over the Earth and denies man the power to exercise his four natural Rights on earth as he wishes and in complete freedom, this Society should allow the individual the RIGHT TO WORK in order to compensate him for the Rights of which he is deprived; then, in principle, and assuming a convenient application, the individual will have no further grounds for complaint.] ([1840] 1848, 24)

Considerant hastened to add the requirement that the reward for this productive activity should be at least as high as that which would have been achieved in the state of nature, which effectively turned him into an advocate of the right to work at a wage sufficient to secure subsistence:

La condition sine quâ non pour la Légitimité de la Propriété est donc que la Société reconnaisse au Prolétaire le DROIT AU TRAVAIL et qu'elle lui assure au moins autant de moyens de subsistance, pour un exercice d'activité donné, que cet exercice ê̂t $p u$ lui en procurer dans l'État primitif. [The condition sine qua non for the Legitimacy of Property is therefore that Society awards to the Proletarian the RIGHT TO WORK and that it guarantees to him at least as many means of subsistence, for a given amount of effort, as this effort could have given him in the State of nature.] (24-25)

This was the minimum condition of a legitimate property regime in accordance with natural rights. However, for Considerant, the duties of such a regime might actually go beyond this; an individual born into a civilized society might have new wants created by that society itself, which would generate a claim to more than would have been available in any state of nature.

Sometimes, therefore, Considerant promoted the Fourierist orthodoxy that the guarantee of a minimum could be given only under a regime of attractive labor. On other occasions, he advocated the right to work as a doctrine that might be realized even under a regime of repugnant labor. In the first case, the entitlement was derived from a natural right to subsistence itself; in the second, it was derived from a natural right to the equal opportunity to gain a subsistence through labor. ${ }^{24}$

24. In a similar vein, the Fourierist writer Zoé Gatti de Gamond ([1838] 1841-42, 42) strongly advocated the minimum, the right to work, and education as compensations for the 


\section{Joseph Charlier}

The right to work was debated widely by socialist thinkers involved in the 1848 revolution in Paris, when leftist parties were in power between February and June and abolished the monarchy. ${ }^{25}$ These debates were followed carefully in Brussels, which acted as a center of refuge for many significant French and German socialists of the period. ${ }^{26}$ Undoubtedly, Joseph Charlier, who first published his views on what was known as the social question-it referred mainly to the condition of the laboring population - in the second half of 1848, was well aware of the ideas that were circulating. Whether or not he was directly reacting to Considerant's views, it is clear that he accepted Considerant's critique of the existing property regime but rejected the adequacy of the right to work as a surrogate for natural rights entitlements. The originality of Charlier is that he argued that those entitlements should be recognized by an unconditional basic income scheme, even under conditions of repugnant labor.

Charlier was born in Brussels on 20 June 1816 and died there on 6 December 1896. He published at least thirteen books, ranging from novels and poetry to works on technical legal issues and social theory. The four key works in that last category were as follows:

- Solution du problème social ou constitution humanitaire, basée sur la loi naturelle, et précédée de l'exposé de motifs (1848). This introduced the scheme for a "guaranteed minimum" funded from the socialization of rent. Charlier explained in detail why he advocated the scheme, and he presented it in the form of a "humanitarian constitution."

- Catéchisme populaire, philosophique, politique et social (1871). Here Charlier refined the core theme of the guaranteed minimum under the new form of "the system of territorial dividend."

\footnotetext{
loss of natural rights: "Ne serait-il pas d'une justice rigoureuse que la société lui donnât un dédommagement équivalent à la perte des droits naturels? N'est-ce pas pour elle un devoir sacré d'assurer à tous ses membres le minimum, le droit au travail et l'éducation ou développement des facultés qui rendent l'homme apte à participer aux bienfaits des arts, des sciences et de l'industrie, cachet de la civilisation?" [Would it not be rigorously right that society offered a person an indemnity equivalent to the loss of that person's natural rights? Is it not a sacred duty for society to guarantee to all its members the minimum, the right to work, and education, or the development of the abilities that allow man to share in the benefits of the arts, sciences, and industry, the mark of civilization?]
}

25. See Tanghe 1989 for an overview of the intellectual discussion on the right to work.

26. Marx and Engels spent some time in Brussels, as did Considerant. 
- La question sociale résolue précédée du testament philosophique d'un penseur (1894b). This is Charlier's most substantial work. He reproduced the relevant sections of the Catéchisme on territorial dividend, included a scheme for pension provision initially suggested in 1887, and introduced another "humanitarian constitution" that was similar but not identical to the 1848 version, together with a set of justifying "interpretative remarks."

- L'anarchie désarmée par l'équité: Corollaire à la question sociale résolue (1894a). This summarized the diagnosis and solution of social issues presented immediately before in La question sociale résolue.

Apart from these texts, we have very little to work with. ${ }^{27}$ His exact profession is unknown; he once classified himself as a "juriste" (1894b, $10), 28$ but in successive population registers his occupation is variously listed as "writer," "accountant," and "merchant." $29 \mathrm{He}$ is considered only in passing in many of the standard sources on the history of socialism in Belgium, and there is no substantial study of either his life or work. ${ }^{30}$

In one of these passing references Charlier is designated as a "Fourierist." 31 This might well be an accurate description, but we have found no evidence to suggest that he played a significant role in Belgian Fourierist

27. Despite our sustained attempts to discover more information, Charlier remains much of a mystery.

28. His preoccupation with legal issues confirms that he was active in some capacity in the Belgian judicial system. On occasions he severely criticized the system as a whole"Toute cette corporation parasite de juges, d'avocats, d'avoués et d'huissiers qui généneralement vivent et s'enrichissent aux dépens de la masse; car tous gens-là ne produisent rien, n'ajoutent pas un atome au capital social" [This whole parasitic corporation of judges, lawyers, bailiffs, and ushers who in general live and enrich themselves at the expense of the masses; because all these people do not produce anything at all, do not add a single atom to the social capital] $(1848,63)$-and notaries in particular: "le notariat n'ajoute rien à la richesse publique" [notaries do not add anything to public wealth] $(1871,41)$. He also characterized himself as an active member of the "Société internationale d'études sociales et politiques" (1894b, 3), by which was meant the "Société d'études sociales et politiques," active in Belgium between 1890 and 1895 (Crombois 1994, 16-20). We are uncertain whether Joseph Charlier is the Charlier who played an active role in the Brussels-based Cercle Démocratique around 1880; see Wouters 1971, 3:1504, 1513, 1518, 1525, 1553.

29. This information has been provided to us by Maryline Van Parijs.

30. References to Charlier have been made by Benoit Malon (1879, 475, 488-89; 1892, 115), Ernest Henrion (1892, 132), Louis Bertrand (1902, 1:175; 1906-7, 2:424, 428-30), Victor Serwy (1948-52, 1:27, 96-97, 4:110), Jan Dhondt (1960, 271), and Bernard Dandois (1974, 21).

31. Serwy (1948-52, 4:110) described him as "publiciste, poète, fouriériste." 
circles. ${ }^{32}$ Although the intellectual provenance of his views is unknown, it cannot be denied that in the Solution, Charlier did indeed present a sympathetic but not uncritical assessment of Fourier and Fourierism. He explicitly (but not unconditionally) praised Fourier and his work, ${ }^{33}$ and he used terms clearly borrowed from the Fourierist tradition. ${ }^{34}$ In all of Charlier's subsequent works, however, neither Fourier nor his theory is referred to, as if Charlier later in life distanced himself from his original source of inspiration.

In the Solution, Charlier $(1848,19)$ insisted in a typically Fourierist manner that the central problem to be addressed was the "amélioration du sort des classes déshéritées" [the improvement of the condition of the disinherited classes]. This was above all a "material question" relating to "physical life": the concern should be with material, not political, rights, and the aim should be to realize "physical" or "material emancipation" but without political or social upheaval. He rejected two currently fashionable responses to the problem: "the right to assistance" addressed only the effects and not the cause of the problem, whereas the "right to work/organization of labor" would result in an unacceptable extension of state control. ${ }^{35}$ Instead, he proposed an alternative solution that both guaranteed natural rights entitlements and respected existing legal titles, through compensation arrangements.

32. Although we cannot state confidently that he was influential in Belgian Fourierist circles, consider that the publication of his 1848 book was signaled in Le débat social, a Brusselsbased journal with Fourierist sympathies, together with the announcement "nous nous empresserons d'en rendre compte quand nous en aurons fait l'examen" [we will do our best to give an account of it as soon as we have examined it] (Le débat social 1848, 217); the promised review never appeared. There is no trace of Charlier in the study by Ernest Discailles (1895) on Considerant's influence in Belgium.

33. "De toutes les doctrines socialistes mises en avant, il n'en est aucune qui puisse être traduit en fait sans jeter la société dans une grande perturbation, en tant du moins qu'elles touchent aux intérêts matériels, le Fouriérisme excepté. Mais le Fouriérisme c'est une merveille orientale qui charme, subjugue et fascine l'esprit, et qu'on admire comme une brillante féerie. Il faut quant à présent une machine moins compliquée, et qui soit surtout dégagée de toute espèce d'illusion" [Of all the socialist doctrines that have been put forward, with the exception of Fourierism, there is none that can be translated into reality without throwing society into a state of disorder, at least with regard to its material interests. But Fourierism is like an Oriental wonder that charms, seduces, and fascinates the mind, and that one admires like a brilliant spectacle. But as of now we need a less complicated device, and above all one that would be clear of any type of illusion] (Charlier 1848, 10; see also 11, 37, 39, and 40).

34. Such as "minimum garanti" (1848, 33, 37), "destinée sociale" (20), "travail ... attrayant" (36), "industries répugnantes" (36), and "garantisme rationnel" (83).

35 . On the right to assistance, see Charlier 1848, 6-7; on the right to work, see Charlier $1848,11-14$. 
Charlier adopted the familiar jurisprudential contrast between natural and produced resources. Like Considerant, he argued that a creatorskeepers principle did not justify individual property rights in land itself, but only in assets resulting from human labor. ${ }^{36}$ That familiar distinction was given a new dimension by Charlier, however. He maintained that natural resources were intended by God to provide a guarantee for the "vital needs" of all persons. Produced assets by contrast were destined to meet the "acquired needs" of each person. ${ }^{37}$ Only the vital needs generated an absolute right: because every human being had the right to live, each person had a right to a share of the fruits of the earth sufficient to provide subsistence. ${ }^{38}$ The essential role of the state consisted in guaranteeing these individual rights to the produce of the common patrimony by ensuring that all were included and none excluded. The acquired needs did not generate a right but merely a discretionary power. ${ }^{39}$ Whether and to what extent these relative needs were fulfilled was a matter for individual choice expressed through labor. For

36. "Le sol à personne, mais le fruit à tous. Telle est la grande, la véritable maxime sur laquelle repose le salut de la société humaine et dont nous allons démontrer la légitimité intrinsèque et les bienfaits" [The land to nobody, but the fruit to all. That is the great, true maxim on which the faith of human society rests and of which we will demonstrate the intrinsic legitimacy and benefits] $(1848,23)$.

37. We use the expression "vital needs" for Charlier's "besoins absolus," "besoins naturels," and "besoins naturels et vitaux," and "acquired needs" for his "besoins relatifs," "besoins artificiels," and "besoins acquis."

38. "L'homme en naissant apporte avec lui le droit de vivre; de ce droit inhérent à son être et que personne à coup sûr n'osera lui contester, découle comme conséquence obligée le droit de demander au sol, patrimoine commun des hommes, sa part dans les fruits nécessaires à son existence" [When he is born man brings with him the right to live; from this right, which is inherent to his being and which surely nobody will dare to contest, follows as a necessary consequence, the right to demand from the land, the common patrimony of men, his share of the fruits that he needs for his existence] $(1848,20)$.

39. "Les besoins absolus sont ceux indispensables à l'entretien de la vie. Ils constituent dans le chef de l'individu un droit.

Les besoins relatifs ou acquis sont ceux que donne le raffinement des sens, et que l'on peut supprimer sans compromettre l'existence. Ils ne constituent qu'une faculté.

Le droit doit être respecté, protégé et satisfait par la société ou l'État.

La faculté, au contraire, ne lui impose aucune obligation; elle doit être abandonnée à l'activité individuelle dont elle est le plus énergique ressort" [The vital needs are those that are indispensable to the support of life. In the mind of the individual they constitute rights.

The acquired needs are those which are provided by the refinement of the senses, and which can be suppressed without threatening existence. They constitute only discretionary powers.

Rights must be respected, protected, and satisfied by society or by the State.

Discretionary powers, on the other hand, do not impose any obligation; they must be left to individual activity of which they are the most energetic incentives] $(1848,24)$. 
Charlier, therefore, entitlements to property should be assigned on dual principles each applying to different domains: common property in natural resources, with guaranteed individual shares in their bounty, but full private property rights in produced assets. So, the fundamental law that symbolized truth and justice was as follows:

Que la propriété foncière, ouvre de Dieu, appartient à l'universalitè des êtres créés: elle est indivisible et immuable comme l'humanité au service de laquelle elle a été affectée et dont elle doit garantir les besoins naturels et vitaux;

Que la propriété mobilière, ouvre de l'homme, est essentiellement personelle: elle est destinée à donner satisfaction aux besoins acquis, en raison directe du dégré d'activité de chacun.

[Landed property, the work of God, belongs to the community of created beings: it is indivisible and invariable like humanity itself, to the service of which it has been intended and of which it must secure the natural and vital needs.

Mobile wealth, the work of man, is essentially personal: it is destined to give satisfaction to the acquired needs, in direct proportion to the degree of activity of each person.] $(1848,39)$

On a more practical level, the problem to be resolved was the implementation of these principles in a setting in which there was private landownership, especially in a concentrated form. Although Charlier emphasized that private landownership was incompatible with the notion of a common natural patrimony, he also insisted that current legal titles to land had to be respected. The proposed resolution hinged on a system of mutual compensation, mediated by the state, between the minority of current landowners and the landless majority. Landowners would be compensated, at least partly and temporarily, for any loss resulting from the reassertion of the collective right to the land. The landless majority would be compensated permanently through the disbursement of a "guaranteed minimum." The state would derive the financial resources for this system of mutual compensation from the socialization of rent and related measures. In Charlier's view, only this mechanism could remedy the injustice of private landownership without introducing another injustice by a forced dispossession of legal titles. He claimed that his "humanitarian constitution" provided a "mathematical solution" to the problem $(1848,21)$. 
Charlier did not limit himself to a general description of the scheme, but consistently with his own injunction against impractical plans, worked it out in great detail and added calculations to show that it was financially sound. ${ }^{40}$ The main question was whether the state would have enough financial resources for the two compensatory payments. As the sole landowner, the state would receive all the existing land-rents; in addition, it would generate new revenue streams by better managing the land. In exchange for the loss of their land, owners would not receive its capital value but instead would be entitled to an annual revenue partly compensating their loss of land-rent income. ${ }^{41}$ The compensating revenue would vary with the wealth of the landowner: the higher the individual fortune of the landowner, the smaller the ratio between revenue and capital would be. 42 Moreover, the revenue would diminish through time according to the number of intergenerational transfers: with each transfer the revenue would decrease by a quarter of its original amount. 43 The difference between the rent revenues of the state and its compensation payments to the original landowners would be the amount available for the guaranteed minimum. Charlier stressed that the right to the minimum was equal and universal, in that it was possessed by each individual from birth: this effectively means that his guaranteed minimum is a basic income in the modern sense. ${ }^{44}$

The level of the minimum would be established annually; in the

40. The calculations applied to Belgium; he arrived at the conclusion that in the first year the scheme would yield an income of about 50 francs per head. For more details, see Charlier $1848,47-50$.

41. Charlier (1848, 48-49) estimated that in Belgium the total rent-income amounted to $670,020,000$ francs; he proposed compensating payments for an amount of 322,000,000 francs, that is, 48 percent of the total land-rent income.

42. For those owning a fortune worth more than 3 million francs, the compensating revenue would be equal to 1.5 percent of the estimated land value; for those owning a fortune between 1 and 3 million francs, the percentage would be 2 percent; finally, for those owning less than 1 million francs, it would be 2.5 percent $(1848,49)$. Later in the pamphlet he changed the upper threshold value to 5 million (105).

43. "La valeur de ces biens sera, après l'estimation cadastrale, ou toute autre mode d'appréciation à déterminer, convertie en rentes viagères au profit des propriétaires et leurs descendants jusqu'à la quatrième génération et par amortissement d'un quart par génération" [Based upon survey estimates or any other valuation method to be decided, the value of these goods will be converted into annuities to the benefit of proprietors and their descendants, and this until the fourth generation and by depreciation of a quarter per generation] $(1848,40-41)$.

44. In appendix 1 we reproduce the relevant articles of the humanitarian constitution of 1848 which make this clear; in appendix 2 we give the corresponding articles of the humanitarian constitution of 1894 . 
beginning it would be fairly low because of the transitional compensation payments to the original landowners, but it would increase as those payments declined and eventually ceased. Payments would be made quarterly, and in cash. The right to the minimum was a personal lifetime one, inalienable and irrevocable. It was inalienable because "membership" in a society was by nationality; but, ultimately, Charlier hoped that this criterion would become redundant as the entitlement came to be calculated on a global basis. Alongside the minimum, which expressed the general obligation of society to guarantee basic necessities for its members, there would be other measures reflecting particular obligations to specific groups. Children would be entitled to education, and the old and the infirm to special care. The state would provide institutions for these purposes funded in part from the transfer of the guaranteed minimum to them $(1848,64,73,82,86)$.

With intriguing minor variations, this diagnosis and the corresponding prescription remained constant throughout all of Charlier's subsequent works on social theory over nearly fifty years. Two of these variations were the change in terminology from "guaranteed minimum" to "territorial dividend" and the increase in the frequency of payment from quarterly to monthly. ${ }^{45}$ In his last two works, Charlier assessed the scheme that had occupied him for most of his life. He listed nineteen advantages such as a reduction of religious rivalries, robberies, and begging, a decrease in legal disputes, the abolition of "the domination of capital over labor," and so forth (1894b, 244-47). The claimed advantages were so many and various that the scheme resembled a panacea. Nevertheless, Charlier also looked at the potential disadvantages. Three of them had worried him since his first advocacy of the scheme. These are particularly fascinating because they directly anticipate some of the reservations that figure prominently even in present-day debates.

The first potential disadvantage concerned the level of payment that could be achieved through a scheme apparently based on the market value of natural resources only. The suspicion was that the aggregate flow of land-rent revenue would be insufficient to cover the basic needs of all, especially after the deduction of the compensation payments to the original landowners (Charlier 1848, 76-77; 1871, 44-45; 1894b, 21112, 226-27). Charlier readily accepted that the initial dividend level would be "necessarily minimal" and probably insufficient to satisfy

45. Compare the appropriate sections in the appendices. 
basic needs. But what about the level once the transitional compensation payments had fallen significantly? Although in some countries the per capita land-rent revenue might be too low to meet vital needs, Charlier believed that on a global scale the dividend generated by the common patrimony would be more than enough. Incidentally, in most of his calculations Charlier did not restrict that patrimony to pure natural resources, that is, to land in its original condition before any changes resulting from human labor. Without offering any explicit justification, he increased the pool considerably by identifying it with "real estate." 46 This category included not only land in its improved form as a result of labor, but also buildings and other fixtures. With one possible exception, no attempt was made to separate the revenue attributable to the original site from the total. 47

The second and related danger was that the provision of a territorial dividend would encourage the population to grow, reducing the per capita level of payment below a subsistence rate (Charlier 1848, 73-74; $1871,64-65 ; 1894 b, 241-42)$. According to Charlier, this would not be the case; any growth (or decline, for that matter) in population would follow the "normal course." Apart from endorsing the familiar appeals to divine providence, he argued rather unpersuasively that a guaranteed minimum would have no effect on parents' calculations (if any) about family size.

The third concern echoed the Fourierist fear that a guaranteed minimum would constitute "une prime d'encouragement à la paresse" [an

46. He moved from "la propriété foncière" to "la propriété immobilière."

47. "La propriété immobilière produit:

A. Les fruits civils, comprenant les loyers pour l'usage du fonds;

B. Les fruits industriels, c'est-à-dire tout ce que l'homme peut, par son travail, en obtenir ou extraire.

Les premiers appartiennent, de droit primordial, aux usufruitiers du fonds commun, en vertu de leur droit sui generis d'usage. Ici, point de propriété personnelle sur le fonds.

Les seconds appartiennent à ceux qui les ont produits; ils constituent dans leur chef le droit d'en disposer selon leur volonté et leur intérêt. Ces produits donnent donc lieu à un droit de propriété absolu en leur faveur" [Real estate produces:

A. Civil benefits, including the rents for the use of the fund;

B. Industrial benefits, that is to say everything that man, by his own labor, can obtain or extract from it.

The first belong, by fundamental right, to the usufructuaries of the common fund, by virtue of their sui generis right of use. In this case, there is no personal property in the fund.

The second belong to those that have produced them; they constitute in their opinion the right to dispose of them according to their wishes and interests. These products create an absolute property right in their favor] (Charlier 1894a, 17-18). 
incentive to be lazy] (Charlier 1848, 35), which would create a new class of "rentiers" (Charlier 1871, 51). Charlier recognized the possibility that some individuals might be content to survive on the dividend alone, but he accepted without reservation that this was their right:

Tant pis pour les paresseux: ceux-là resteront réduits à la portion congrue. Le devoir de la société ne va pas au delà: assurer à chacun sa juste participation à la jouissance des éléments que la nature a mis à son service, sans usurpation des uns au préjudice des autres. [Too bad for the lazy: they will have to get by with the minimum allowance. The duty of society does not go beyond this: to assure to everyone his fair share in the enjoyment of the elements that nature has put at his disposal, without usurpation by some people to the detriment of others.] (1894b, 56)

Charlier was convinced, however, that this would hold only for a minority; for the majority, the dividend scheme would actually be an incentive to labor. The security derived from the guarantee of basic needs would allow individuals to concentrate on satisfying the expanding domain of their acquired wants, which could be achieved only through labor itself. Moreover, that security would promote the independence and dignity of each human being, liberating all from the tyranny of dependence on others, especially for the satisfaction of basic needs (Charlier 1894b, 54$55)$.

\section{Conclusion}

We have demonstrated that the largely neglected Belgian writer, Joseph Charlier, presented as early as 1848 a fully developed basic income scheme, strikingly similar in all significant respects to contemporary proposals. In Charlier's scheme, as in modern proposals, a basic income would be paid unconditionally to each individual member of societyas a right-without work requirements or means testing. In one respect it goes even further than most of today's basic income plans, since each individual would be entitled to receive the full amount from birth. Moreover, the guaranteed income would be substantial, at or near the prevailing level of subsistence. In defending his program, Charlier directly anticipated objections to basic income that still figure prominently in present-day controversies. The fundamental objection is that a basic income licenses the exploitation of those willing to make a productive 
contribution by those unwilling to do so. Charlier directly admitted this possibility, but denied its relevance in the context of the unconditional right of each person to enjoy a basic living standard. By means of calculations he tried to establish that a substantial basic income could be sustained by capturing the rewards of fixed property.

The initial inspiration of Charlier's views undoubtedly lay in the Fourierist tradition. We have shown that this tradition did support the idea of a minimum, but not that of an unconditional one. For Fourier the minimum could be realized only under a regime of attractive labor, and even then it would be restricted to the poor and provided in kind rather than in cash. Considerant endorsed Fourier's view, but also advocated the right to work as a more politically realistic possibility. Charlier's truly remarkable novelty lay in his sustained advocacy of an unconditional monetized minimum, which was dependent neither on attractive labor nor the right to work and could therefore be introduced almost immediately.

\section{Appendix 1}

[from Solution du problème social ou constitution humanitaire, basée sur la loi naturelle, et précédée de l'exposé de motifs (1848), by Joseph Charlier]

CONSTITUTION HUMANITAIRE, ou

\section{LOI ORGANIQUE}

Basée sur la loi naturelle

ART. 2. Par cela seul que l'homme existe il a le droit de vivre. Ce droit, absolu comme le principe dont il dérive, trouve sa garantie dans le règne végétal créé en vue des besoins physiques de l'humanité. Le sol est donc essentiellement propriété collective, et à ce titre ne peut appartenir en propre à des particuliers; les hommes ne sont que les usagers de la terre.

En conséquence le droit de propriété territoriale réside dans l'État.

Toute possession contraire à ce principe sera rachetée comme attentoire au droit collectif de l'humanité.

ART. 3. Les revenus territoriaux seront perçus par l'État au profit de la collection, comme propriété nationale, et serviront à garantir à chaque 
membre de la société, sans distinction d'âge ni de sexes, un minimum pour la substantation de ses besoins absolus.

ART. 4. Ce minimum sera fixé annuellement par le grand conseil représentatif de la nation, sur la valeur locative des immeubles, déduction faites des charges publiques.

ART. 5. Le droit au minimum est personnel. Il naît et meurt avec l'individu.

Il est inaliénable et insaisissable.

Néanmoins l'émigration non autorisée en entraînera la suspension pour toute la durée de l'absence; et la perte définitive en cas de résidence à l'étranger sans esprit de retour ou de condamnation pour attentat contre la sûreté extérieure de l'État.

Il sera payé à chaque individu trimestriellement et en espèces, sur la présentation de son brevet d'indigénat, en marche duquel chaque payement sera annoté.

\section{[HUMANITARIAN CONSTITUTION}

or

ORGANIC LAW

Based upon the natural law

ART. 2. By the mere fact that he exists, man has the right to live. This right, which is as absolute as the principle from which it is derived, is guaranteed by the plant kingdom created in view of the physical needs of humanity. The land is therefore essentially collective property and for this reason cannot be owned by individuals.

Men are only the users of the earth.

By consequence, the right of territorial property belongs to the State.

Every possession that is contrary to this principle will be repurchased because it violates the collective right of humanity.

ART. 3. The territorial revenues will be perceived by the State as national property to the benefit of the whole and will be used to guarantee to each member of society, without distinction of age or sex, a minimum for the satisfaction of his vital needs.

ART. 4. This minimum will be fixed annually by the great council which represents the nation, based upon the rent value of immobile wealth, after deduction of the expenses of the state. 
ART. 5. The right to the minimum is personal. It is born and dies with the individual. It is inalienable and immune from confiscation.

Nevertheless, unauthorized emigration will occasion the suspension of the minimum during the whole period of absence. In the case of residence abroad without the intention of return, or of condemnation for assault against the external security of the State, the minimum will be lost for good.

It will be paid to each individual per trimester and in money, on the presentation of his passport, in the margin of which each payment will be recorded.]

\section{Appendix 2}

[from La question sociale résolue précédée du testament philosophique d'un penseur (1894), by Joseph Charlier] CONSTITUTION HUMANITAIRE BASÉE SUR LA LOI NATURELLE.

ARTICLE PREMIER.—L'homme en naissant apporte avec lui le droit de vivre. La vie humaine est sacrée.

ART. 2.-La jouissance du droit à la conservation de la vie lui est garantie par la loi suprême qui régit les mondes, et qui a mis au service de cette conservation les quatre éléments primordiaux constituant le patrimoine commun de tous:

$A$. Le soleil qui l'éclaire;

$B$. L'air qu'il respire;

$C$. L'eau qui le désaltère;

$D$. La terre pour le nourrir.

ART. 3.- Il ne peut être établi aucun droit de propriété individuel sur ce patrimoine, œuvre de Dieu, l'homme n'étant que le simple usager de la terre. ...

ART. 18.- Il sera délivré, à la naissance de chaque enfant, un carnet dans la forme prescrite par la loi pour la perception du dividende territorial, lequel sera établi, chaque année, sur les bases arrètées par le gouvernement et approuvées par les Chambres.

Il sera payable par douzième au bureau du préposé dans chaque commune. 
ART. 19.- - Le dividende territorial est inaliénable, incessible et insaisissable, pour n'importe quelle cause.

ART. 20.-L'indigène qui se fixera à l'étranger pour une période de plus de cinq années perdra son droit au dividende territorial.

ART. 21.-Les étrangers établis en Belgique et leurs descendants jusqu'à la troisième génération, nés dans le pays, ne pourront participer aux dividendes territoriaux, sauf les cas de grande naturalisation ou de réciprocité de leur pays d'origine, et moyennant que les descendants aient fait connaître leurs volonté de faire partie de la nation.

\section{[HUMANITARIAN CONSTITUTION BASED UPON THE NATURAL LAW.}

FIRST ARTICLE.-When he is born man brings with him the right to live. Human life is sacred.

ART. 2.- The exercise of the right to the conservation of life is guaranteed by the supreme law that governs the world and that has provided for this conservation the four fundamental elements that constitute the common patrimony of all:
A. The sun that gives him light;
B. The air that he breaths;
C. The water that satisfies his thirst;
D. The land to feed him.

ART. 3.-There cannot be established any individual property right on this patrimony, the work of God, since man is but a simple user of the land. ...

ART. 18.-At the birth of each child, a booklet will be delivered in the form prescribed by the law for the receipt of the territorial dividend. This dividend will be determined each year, on the basis of what has been decided by the government and approved by the parliament.

It will by paid monthly in the office of the government's agent in each community.

ART. 19.- - The territorial dividend is inalienable, nontransferable, and immune from confiscation, for any reason whatsoever.

ART. 20.-The indigenous person who lives abroad for a period of more than five years will lose his right to the territorial dividend.

ART. 21.-The foreigners living in Belgium, and their descendants born in the country until the third generation, cannot participate in the 
territorial dividends, except in the cases of full naturalization or of reciprocity with their countries of origin, and on condition that the descendants have shown their willingness to be part of the nation.]

\section{References}

Beecher, J. 1986. Charles Fourier: The Visionary and His World. Berkeley: University of California Press.

Beecher, J., and R. Bienvenu, eds. and trans. 1983. The Utopian Vision of Charles Fourier: Selected Texts on Work, Love, and Passionate Attraction. Columbia: University of Missouri Press.

Bertrand, L. 1902. Histoire de la coopération en Belgique. Les hommes-Les idéesLes faits. 2 vols. Brussels: Dechenne \& Cie.

-1906-7. Histoire de la démocratie et du socialisme en Belgique depuis 1830. 2 vols. Brussels: Dechenne \& Cie.

Charlier, J. 1848. Solution du problème social ou constitution humanitaire, basée sur la loi naturelle, et précédée de l'exposé de motifs. Brussels: Chez tous les libraires du royaume.

- 1871. Catéchisme populaire, philosophique, politique et social. Brussels: Typ. De Ch. et A. Vanderauwera.

- 1894a. L'anarchie désarmée par l'équité: Corollaire à la question sociale résolue. Brussels: $\mathrm{P}$. Weissenbruch.

-1894b. La question sociale résolue précédée du testament philosophique d'un penseur. Brussels: P. Weissenbruch.

Cole, G. D. H. 1953-60. A History of Socialist Thought. 5 vols. London: Macmillan.

Considerant, V. 1834-44. Destinée sociale. 3 vols. Paris: Au bureau de la Phalange et chez les Libraires du Palais-Royal.

— . [1840] 1845. Exposition abrégée du système phalanstérien de Fourier. 3d ed. Paris: Librairie Sociétaire.

- [1840] 1848. Théorie du droit de propriété et du droit au travail. 3d ed. Paris: Librairie Phalanstérienne.

- 1848. Le socialisme devant le vieux monde, ou le vivant devant les morts. Paris: Librairie Phalanstérienne.

Crombois, J.-F. 1994. L'univers de la sociologie en Belgique de 1900 à 1940. Brussels: Editions de l'université de Bruxelles.

Dandois, B., ed. 1974. Entre Marx et Bakounine: César De Paepe. Correspondance. Paris: François Maspero.

Davidson, R. Van. 1988. Did We Think Victory Great? The Life and Ideas of Victor Considerant. New York: University Press of America.

Le débat social. 1848. 1er octobre, 5e année, no. 25.

Del Bo, G. 1957. Charles Fourier e la Scuola Societaria (1801-1922): Saggio Bibliografico. Milan: Feltrinelli Editore. 
Dhondt, J., ed. 1960. Geschiedenis van de Socialistische Arbeidersbeweging in België. Antwerp: S. M. Ontwikkeling.

Discailles, E. 1895. Le socialiste français Victor Considerant en Belgique. Bulletin de l'académie royale des sciences, des lettres et des beaux-arts de Belgique, $3 \mathrm{~d}$ ser., year 55, vol. 29, pp. 705-48.

Fourier, C. [1803] 1874. Lettre de Fourier au grand juge. Edited by C. Pellarin. Paris: Dentu.

- [1803-4] 1966-68. Les trois nœuds du mouvement. In vol. 12 of Euvres complètes de Charles Fourier. Paris: Anthropos.

. [1806] 1966-68. Du plan providentiel. In vol. 11 of Euvres complètes de Charles Fourier. Paris: Anthropos.

- [1808] 1966-68. La théorie des quatre mouvements. Vol. 1 of Euvres complètes de Charles Fourier. Paris: Anthropos.

_ [1822] 1966-68. Traité de l'association domestique-agricole. 2 vols. Vols. 2-5 of Euvres complètes de Charles Fourier. Paris: Anthropos. Reissued under the title La théorie de l'unité universelle in 1841-43.

- [1829] 1966-68. Le nouveau monde industriel et sociétaire. Vol. 6 of Euvres complètes de Charles Fourier. Paris: Anthropos.

- [1835-36] 1966-68. La fausse industrie. 2 vols. Vols. 8-9 of Cuvres complètes de Charles Fourier. Paris: Anthropos.

- [1852] 1966-68. Des manuscrits de Charles Fourier. Vol. 2. In vol. 10 of Euvres complètes de Charles Fourier. Paris: Anthropos.

_ . [1857-58] 1966-68. Des manuscrits de Charles Fourier. Vol. 4. In vol. 11 of Euvres complètes de Charles Fourier. Paris: Anthropos.

-1966-68. Le nouveau monde amoureux. Vol. 7 of Euvres complètes de Charles Fourier. Paris: Anthropos.

Gatti de Gamond, Z. [1838] 1841-42. Fourier et son système. 5th ed. Paris: Capelle. Henrion, E. 1892. Le socialisme en Belgique. Almanach de la question sociale et du centenaire de la République (Revue annuelle du socialisme internationale), deuxième année, 131-37.

Malon, B. 1879. Histoire du socialisme depuis ses origines probables jusqu'à nos jours. Lugano-Castagnola.

. 1892. Précis historique, théorique et pratique de socialisme. Paris: Félix Alcan.

Mill, J. S. [1848] 1965. Principles of Political Economy, with Some of Their Applications to Social Philosophy. Toronto: University of Toronto Press.

Nozick, R. 1974. Anarchy, State, and Utopia. Oxford: Blackwell.

Poulat, É. 1957. Les cahiers manuscrits de Fourier: Étude historique et inventaire raisonné. Paris: Editions de Minuit \& Entente Communautaire B.E.C.C.

Serwy, V. 1948-52. La coopération en Belgique. 4 vols. Brussels: Les propagateurs de la coopération. 
Tanghe, F. 1989. Le droit au travail entre histoire et utopie, 1789-1848-1989: De la répression de la mendicité à l'allocation universelle. Travaux et Recherches, Facultés universitaires Saint-Louis, no. 16. Brussels: Facultés universitaires SaintLouis.

Van Parijs, P. 1992. Competing Justifications of Basic Income. In Arguing for Basic Income: Ethical Foundations for a Radical Reform, edited by P. Van Parijs, 3-43. London: Verso.

Van Trier, W. 1995. Every One a King. Ph.D. diss., Katholieke Universiteit Leuven.

Vernus, M. 1993. Victor Considerant, 1808-1893: Le cœur et la raison. Dole \& Saint-Imier: Canevas Editeur.

Wouters, H., ed. 1971. Documenten betreffende de Geschiedenis van de Arbeidersbeweging ten Tijde van de I Internationale (1866-1880). 3 vols. Leuven: Editions Nauwelaerts. 